IRSH 54 (2009), pp. 207-236 doi:I0.1017/So020859009000698

(C) 2009 Internationaal Instituut voor Sociale Geschiedenis

\title{
"I Fear You Will Think Me Too Presumtuous in My Demands but Necessity Has No Law”: Clothing in English Pauper Letters, I 800-I 834
}

\author{
STEVEN KING \\ Department of History, Oxford Brookes University \\ E-mail: sking@brookes.ac.uk
}

Summary: This article investigates the way in which the English poor used the rhetoric of clothing in their engagement with local officials as they attempted to secure poor relief. Using letters written about or by the dependent poor from a wide selection of English communities, the article suggests that the poor employed concepts such as raggedness, lost clothing, nakedness, compromised dignity, and community presence and the link between poor clothing and unemployment, to assert their deservingness. An exemplar of a series of letters from the same person is used to explore how paupers developed the rhetoric of clothing over a sustained period of correspondence, suggesting that paupers had a keen appreciation of the impact of compromised clothing in their negotiations with officials. Ultimately, this paper will argue, paupers and officials had a shared concept of minimal clothing standards and a shared linguistic register for linking clothing and deservingness.

\section{INTRODUCTION}

The literature on the clothing of the English labouring classes has expanded significantly since the ground-breaking work of Lemire, Buck, Shammas, Styles, and Weatherill called attention to the period of the long eighteenth century as one of substantial change in dress, fabric, fashion, and the transmission mechanisms of clothing. ${ }^{\mathrm{I}}$ We now have a much better understanding of the development of a textile-retail culture and the

I. Beverley Lemire, Fashion's Favourite: The Cotton Trade and the Consumer in Britain I600-I800 (Oxford, I991); Carole Shammas, The Pre-Industrial Consumer in England and America (Oxford, I990); John Styles, "Clothing the North: The Supply of Non-Elite Clothing in the Eighteenth Century North of England", Textile History, 25 (1994), pp. 139-166; Anne Buck, Dress in Eighteenth Century England (London, 1979); Lorna Weatherill, Consumer Behaviour and Material Culture in Britain 1600-1760, 2nd edn (London, 1996); also contributions to John Brewer and Roy Porter (eds), Consumption and the World of Goods (London, 1993). 
rise of the ready-made trade, and of the relationship of shops, textile products, and consumerism to issues of crime. ${ }^{2}$ The second-hand trade has also attracted considerable attention, and it is clear that poorer consumers in particular had access to a considerable spectrum of clothing gradated by quality, price, and fashionability. ${ }^{3}$

Throughout Europe, it is now clear that ordinary consumers aspired to improve the material culture of clothing, given the multi-layered practical and symbolic significance of what was worn, how, where, and how often. ${ }^{4}$ In turn, we have gained a much better knowledge of the role of clothing, particularly fashionable clothing, in shaping the identity of different social groups and, more widely, in conveying the meaning of status, resistance, and participation in contemporary material culture and gender identity. ${ }^{5}$ As Ross has most recently reminded us, clothing "forms a language, if a restricted one", conveying identity, "which [in itself] is of course continually shifting, being manipulated and reformulated by clothing", amongst other influences. ${ }^{6}$ The theoretical, technical, and methodological

2. Exemplified, for instance, in Tammy Whitlock, Crime, Gender and Consumer Culture in Nineteenth Century Britain (Aldershot, 2005), and Beverley Lemire, Dress, Culture and Commerce: The English Clothing Trade Before the Factory (London, 1997). See also Pamela Sharpe, "Cheapness and Economy': Manufacturing and Retailing Ready-Made Clothing in London and Essex, I 830-1850", Textile History, 26 (1995), pp. 203-2 I 3; Stanley Chapman, "The 'Revolution' in the Manufacture of Ready-Made Clothing I840-I860”, London Journal, 29 (2004), pp. 44-6I.

3. Beverley Lemire, "Peddling Fashion: Salesmen, Pawnbrokers, Tailors, Thieves and the Second-Hand Clothes Trade in England 1700-1800", Textile History, 22 (1991), pp. 67-82; Miles Lambert, "Cast-off Wearing Apparel: The Consumption and Distribution of SecondHand Clothing in Northern England during the Long Eighteenth Century", Textile History, 35 (2004), pp. I-26. For a fine discussion, see Chapman, “The 'Revolution'”, pp. 5I-55.

4. See, for instance, Harald Deceulaer, "Between Medieval Continuities and Early Modern Change: Proto-industrialization and Consumption in the Southern Low Countries (1300-1800)", Textile History, 37 (2006), pp. 104-1 23.

5. See Diana Crane, Fashion and its Social Agenda: Class, Gender and Identity in Clothing (Chicago, IL, 2000); John Styles, "Custom or Consumption? Plebeian Fashion in Eighteenth Century England", in Maxine Berg and Elizabeth Eger (eds), Luxury in the Eighteenth Century: Debates, Desires and Delectable Goods (Basingstoke, 2002), pp. I03-I I 8; Barbara Burman and Carole Turbin, "Material Strategies Engendered", in idem (eds), Material Strategies: Dress and Gender in Historical Perspective (Oxford, 2003), pp. I-I I; and Carlo Belfanti and Fabio Giusberti, "Clothing and Social Inequality in Early Modern Europe: Introductory Remarks", Continuity and Change, is (2000), pp. 359-365. For work on the earlier period, see Susan Vincent, "When I am in Good Habitt': Clothes in English Culture I 5 50-I670", (unpublished Ph.D. thesis, University of York, 2002). The most recent discussions of these issues are to be found in John Styles, The Dress of the People: Everyday Fashion in Eighteenth-Century England (New Haven, CT, 2007), and Barbara Burman and Jane White, "'Changing Her Gown and Setting Her Head to Rights': New Shops, New Hats and New Identities”, in Jennie Batchelor and Cora Kaplan (eds), Women and Material Culture, I660-I830 (Basingstoke, 2007), pp. 74-IOI.

6. Robert Ross, Clothing: A Global History (Cambridge, 2008), pp. 6, 8. 
approaches to dress have also been considerably refined and we have an increasing understanding of garments as items which themselves have histories, histories which are crucial to an understanding of the social history of the wearer, the networks within which they lived their lives, and the sorts of transactional histories within which their everyday activities were enmeshed.?

However, much of this work still elides the clothing experiences of the labouring classes (sometimes the "labouring poor"), and marginal groups such as prostitutes, ${ }^{8}$ with those of the dependent poor, that is the poor who were recipients of transient or longer-term relief from the English Poor Law. ${ }^{9}$ This conflation of different categories of "the poor" is to some extent understandable, given that a typical life-cycle would be likely to include periods of poverty and need (individual or family) interspersed with periods of independence. Unpicking what was distinctive about the clothing of the dependent poor, or at least the labouring poor in their dependency phases, might thus prove problematic. New work on clothing charities and the gift relationship, showing that the poor had real alternatives to clothing provided by the Poor Law as long as they were willing to enter an implicit cultural contract with donors and charity organisers, adds to this problem. ${ }^{10}$ Indeed, to focus on the dependent poor might be to privilege the material culture and strategies of particular sub-groups of the population who were likely to spend longer periods of time on poor relief, such as the aged.

Yet, notwithstanding these potential problems, several textile historians have begun to see the clothing culture of the dependent poor as (positively or negatively) distinctive. Thus, Anne Buck has argued that in Bedfordshire the same trades-people who supplied textiles to the gentry and middle sort also supplied the Poor Law, which was a major source of demand for ready-made clothing (including, particularly, shoes) as well as

7. Lou Taylor, The Study of Dress History (Manchester, 2002); Janet Hoskins, Biographical Objects: How Things Tell the Stories of People's Lives (London, 1998). Also, still pertinent are contributions to A. Appadurai (ed.), The Social Life of Things: Commodities in Cultural Perspective (Cambridge, 1986), and, on transactional processes, Lemire, "Peddling Fashion", pp. $67-82,80$.

8. Melissa Mowry, "Dressing Up and Dressing Down: Prostitution, Pornography and the Seventeenth-Century English Textile Industry”, Journal of Women's History, I I (1999), pp. $78-96$.

9. On the English Poor Law, see Lynn Hollen Lees, The Solidarities of Strangers: The English Poor Laws and the People 1700-1949 (Cambridge, I998).

ı०. See, for instance, Sarah Lloyd, "Agents in their Own Concerns? Charity and the Economy of Makeshifts in Eighteenth-Century Britain”, in Steven King and Alannah Tomkins (eds), The Poor in England 1700-1850: An Economy of Makeshifts (Manchester, 2003), pp. 100-136; Donna Andrew, "To the Charitable and Humane: Appeals for Assistance in the Eighteenth Century London Press", in Hugh Cunningham and Joanna Innes (eds), Charity, Philanthropy and Reform (Basingstoke, 1998), pp. 87-107; Donna Andrew, Philanthropy and Police: London Charity in the Eighteenth Century (Princeton, NJ, 1989). 
cloth and clothing repairs. Indeed, she concludes, "those clothed by the parish were not expected to make their own clothes, nor even to mend them", in contradistinction, it might be argued, to the general labouring population. ${ }^{\text {I }}$ The aim of the Poor Law was to meet "the basic needs in as cheap and lasting a form as possible", but at least those needs were supplied and a baseline of material standards was set. The poor, in other words, came to understand the meaning of adequate clothing, both in terms of quantity and quality. ${ }^{\mathrm{I}}$

Bedfordshire may have been unusual in terms of the nature of Poor Law administration and the generosity of allowances in cash and kind. However, Catherine Richardson has argued more widely that fulfilling pauper requests for clothing had consequences for the public image of the Poor Law and was a significant factor in creating an entitlement precedent or fostering a sense of belonging. She reminds us that seventeenth-century paupers (and one might just as well extend this conclusion to the eighteenth century) were still part "of the social world which demands appropriate outer attire in the presence of friends and neighbours". They were, in other words, on the same material and expectational spectrum as the middling sorts whose rates and charitable donations were spent in supplying clothing needs. This should not surprise us, for, as Ross shows, gaining "respect, and a hearing" was intimately tied up with acceptable and appropriate clothing standards in societies across the modern world. ${ }^{{ }^{3}}$

The work of Snell on the cultures and symbolism of belonging to the English parish also suggests that the Poor Law might be peculiarly susceptible to claims that maintaining the clothing of the poor contributed to the very fabric of village and parish life. ${ }^{\mathrm{I}}$ Moreover, there is accumulating primary evidence that both urban and rural Poor Law authorities in the late eighteenth and early nineteenth centuries did spend considerable amounts on clothing for the poor and that such clothing was of more than simply the meanest and most basic sort. ${ }^{15}$ Alannah Tomkins has shown that parish clothing was sufficiently valuable to attract a good price at the pawnbrokers. ${ }^{16}$ I have also argued that overseers were keenly attuned to

I I. Anne Buck, "Buying Clothes in Bedfordshire: Customers and Tradesmen 1700-1800", Textile History, 22 (1991), pp. 2 I I-237, 233.

I 2. Buck, Dress in Eighteenth Century England, pp. I54-155.

I 3. Catherine Richardson, "Havying Nothing upon Hym Saving Onely His Sherte': Event, Narrative and Material Culture in Early Modern England", in idem (ed.), Clothing Culture 1350-1650 (Aldershot, 2004), pp. 209-221 and 21 5-216; Ross, Clothing, p. 39.

14. Keith Snell, Parish and Belonging: Community, Identity and Welfare in England and Wales, 1700-1950 (Cambridge, 2006).

I5. Perhaps supported by the fact that many paupers had previously been servants and knew what "good" clothing was. See Buck, Dress in Eighteenth Century England, pp. 106-1 19.

16. Alannah Tomkins, The Experience of Urban Poverty 1723-1782: Parish, Charity and Credit (Manchester, 2006). 
the need to provide paupers with decent (in terms of quantity and quality) and even relatively fashionable cloth, bedding, and clothing, reflecting both an awareness of the stigma and disabling nature of poor clothing and also the importance of the reputation of the parish. ${ }^{17}$

Peter Jones, working on the early nineteenth-century Hampshire parishes of Ringwood and Amport, questions the idea that parishes clothed their paupers well, suggesting that "compassionate pragmatism" tended towards some uniformity in clothing and the buying of what was functional. Clothing policies, he argues, varied between parishes, particularly with regard to the stock of clothes given and the gender and age focus of such provision. Nonetheless, he concludes, few paupers applying for clothing relief can have expected anything other than success, reflecting an element of custom in clothing provision and perhaps a shared understanding of the changing standards of clothing that accompanied wider eighteenth- and nineteenth-century developments in taste, comfort, and the domestic environment. ${ }^{18}$

Other textile historians have not been nearly so positive. Jutte's European survey points to the "pitifully low level of clothing" of the labouring poor, and argues that "the poorest among the [non-institutionalized] labouring poor were dressed in worn, stained, patched clothes". ${ }^{9}$ Beverley Lemire offers more detailed empirical nuance, arguing that by the eighteenth century calico and printed linen had become fabrics of choice, and using pawnbroker records to suggest that poor labouring people were not without clothing choices. Indeed, for the humble "individually fashioned attire was more important than the comfort of clothing". Her engagement with the dependent poor is more sceptical. Institutional paupers, she notes, "traded a greater measure of security for public stigmatization" in the sense of uniforms, while for the dependent poor more generally she argues that changes in the range and type of clothing and fabric was heavily protracted. For the very poor, linens and cottons did not, or at least not quickly, become a "normal facet of dress". ${ }^{\circ}$ Lynn Hollen Lees likewise suggests that, particularly post-I800, overseers

17. Steven King, "Reclothing the English Poor 1750-1840", in Steven King and Christiana Payne (eds), The Dress of the Poor, I700-1900 (special edn of the journal, Textile History, 2002), pp. 37-47; Steven King, "The Clothing of the Poor: A Matter of Pride or a Matter of Shame?", in Andreas Gestrich, Steven King, and Lutz Raphael (eds) Being Poor in Modern Europe: Historical Perspectives, I800-1949 (Berne, 2006), pp. 365-388.

18. Peter Jones, "The Clothing of the Poor in Early Nineteenth Century England", Textile History, 37 (2006), pp. 17-37. Note too Ross, Clothing, pp. 31-32, who argues that Britain experienced an eighteenth-century "sartorial union" which would also have increased awareness of changing standards.

19. Robert Jütte, Poverty and Deviance in Early Modern Europe (Cambridge, I994), p. 79.

20. Beverley Lemire, "'Second-Hand Beaux and Red-Armed Belles': Conflict and the Creation of Fashions in England I660-1800", Continuity and Change, Is (2000), pp. 39I-4I7, 395, 397, 
contested claims for cloth and clothing and sought to provide the minimum possible level of support as relief bills spiralled. ${ }^{21}$

Moreover, in the sense that badging the clothing of the poor to create a sense of stigmatization probably lasted rather longer than the 1750 cut-off point of Steve Hindle's article on this issue, it is easy to see how a more pessimistic view on pauper clothing might be constructed. ${ }^{22}$ Certainly Vivienne Richmond argues that, from the I820s, ingrained practices of clothing the poor came under sustained attack, with clothing clubs, Dorcas Societies, and other charitable activity taking up the slack in the budgets of the very poor. ${ }^{23}$ Most recently, John Styles has also suggested that parishes rarely brought the material or clothing that marked out the dress of the upper labouring and lower-middle-sorts, and that while the range of clothing purchased by the Poor Law improved in the late eighteenth century, economy, uniformity, and coarse material still held sway. ${ }^{24}$

This spectrum of opinion on the material culture of the dependent poor may reflect a complex set of regional, intra-regional, and local variations in Poor Law attitudes towards pauper clothing, the life-cycle stages of paupers analysed, and the definition of "the poor" adopted or the particular years chosen. It might also reflect the relative lack of micro-studies on the materiality of pauper clothing; more work on the huge numbers of accounts, bills, samples, vestry minutes, and overseers' accounts that can be used to reconstruct parish clothing strategies is clearly necessary. ${ }^{25}$ However, within this framework, there is an even more glaring lacunae, in the sense that neither welfare nor textile historians have really considered how paupers felt about and used issues of pauper clothing in their engagement with overseers. We have not looked at clothing as part of the agency of the poor, at once a lived experience, part of the sense and concept of dignity, and a discursive strategy with which to confront the overseer and thus establish and maintain entitlement. Crudely, does the way in which paupers described their clothing needs and used them to

399, 406; Beverley Lemire, “'A Good Stock of Cloaths': The Changing Market for Cotton Clothing in Britain 1750-1800", Textile History, 22 (1991), pp. 3 I I-328, 317.

2 I. Hollen Lees, The Solidarities of Strangers.

22. Steve Hindle, "Dependency, Shame and Belonging: Badging the Deserving Poor I 550-1750", Cultural and Social History, I (2004), pp. 6-35. See also Tim Hitchcock, "Tricksters, Lords and Servants: Begging, Friendship and Masculinity in Eighteenth-Century England", in Laura Gowing, Michael Hunter, and Miri Rubin (eds), Love, Friendship and Faith in Europe 1300-I800 (Basingstoke, 2005), p. 190, who suggests that parish clothing might be seen as an affront to the masculinity of the male pauper.

23. Vivienne Richmond, "No Finery': The Dress of the Poor in Nineteenth Century England", (unpublished Ph.D. thesis, Goldsmiths College, 2004).

24. Styles, "Custom or Consumption?", p. I I2; idem, Dress of the People, pp. 257-275.

25. Though see Ann Saunders, "Provision of Apparel for the Poor in London 1630-1680", Costume, 40 (2006), pp. 40-58. 
try and establish entitlement to material and monetary relief point to the sorts of ingrained and pervasive pauper agency that has come to be an increasingly familiar part of the British and European literature, or was that agency heavily circumscribed in the ways variously described by Peter King or Anne Winter? ${ }^{26}$

For late eighteenth- and early nineteenth-century England these intertwining themes of agency, material culture, and the nature of entitlement to clothing under the Old Poor Law can be explored through a large body of pauper letters. Such narratives were written by, for, or on behalf of those paupers who lived in host communities that were not their parish of settlement, in a system known as out-parish relief. ${ }^{27}$ Crudely, these were letters which requested poor relief in the paupers' host communities rather than the paupers be forced to return "home" to their settlement parishes. Those who remained resident in their settlement parishes did not need to write such letters because they could appeal directly to local officials, though vestry minutes do suggest that paupers who made their case in person had a similar range of concerns and rhetorical strategies to those who wrote for their relief.

In the early I 990 s it was thought that the survival of pauper narratives was rare. ${ }^{28}$ Subsequent research has suggested this assumption to be false. Many thousands of letters have been miscatalogued, and their chronological range is now seen to extend to the early twentieth century. ${ }^{29}$ Of course, using such narratives raises a whole host of potential problems. ${ }^{30}$ Who really wrote pauper letters? Was it the pauper or a scribe, and if the

26. Peter King, "Social Inequality, Identity and the Labouring Poor in Eighteenth Century England", in Henry French and Jonathan Barry (eds), Identity and Agency in England I 500-I 800 (Basingstoke, 2004), pp. 60-87; Anne Winter, "Caught Between Law and Practice: Migrants, and Settlement Legislation in the Southern Low Countries in a Comparative Perspective, c.1700-1900", Continuity and Change, I9 (2008), pp. I37-162.

27. On the out-parish system see Steven King, "'It is Impossible for Our Vestry to Judge His Case into Perfection from Here': Managing the Distance Dimensions of Poor Relief, I 800-40", Rural History, i6 (2005), pp. I6I-I89.

28. See contributions to Tim Hitchcock, Peter King and Pam Sharpe (eds), Chronicling Poverty: The Voices and Strategies of the English Poor, I640-I 840 (Basingstoke, I997).

29. Steven King, Thomas Nutt, and Alannah Tomkins, Narratives of the Poor in Eighteenth Century Britain (London, 2006).

30. For the authoritative rendering of such problems see Thomas Sokoll, Essex Pauper Letters $I 73 I-I 837$ (Oxford, 200I). Many of the problems in using pauper narratives are shared by other narrative forms. See Roland Barthes, "Introduction to the Structural Analysis of Narratives", in Stephen Heath (ed.), Image-Music-Text (London, I977), pp. I2 I-I46; Hayden White, The Content of the Form: Narrative Discourse and Historical Representation (Baltimore, MD, 1987); Alan McKenzie (ed.), Sent as a Gift: Eight Correspondences from the Eighteenth Century (Athens, OH, 1993); Clare Brant, Eighteenth Century Letters and British Culture (Basingstoke, 2006); Elizabeth MacArthur, Extravagant Narratives: Closure and Dynamics in the Epistolary Form (Princeton, NJ, 1990); and Temma Berg, The Lives and Letters of an Eighteenth Century Circle of Acquaintances (Aldershot, 2006). 
latter, does the letter really reflect the words and experiences of the pauper ? $^{3 \mathrm{I}}$ Did correspondents follow standard letter-writing manuals, given that these were increasing in number, or are we genuinely picking up the common voice? ${ }^{32}$ Are the pauper letters that survive really representative of all of those that were written but not kept? Do pauper letters accurately reflect the range of concerns, rhetoric/language and strategy of those paupers who applied for relief in person? Do pauper letters simply employ discursive strategies, expressing what the pauper thought his or her home parish might want to hear, or do they convey accurate information about the material culture of the poor? ${ }^{33}$

Historians using them have found considerable internal evidence to suggest that pauper narratives were generally written by the person who signed them, while none of the letter samples analysed so far evidence any systematic use of letter-writing manuals. ${ }^{34}$ Rather, literacy was more widely embedded by the later eighteenth century than it has been usual to acknowledge. ${ }^{35}$ Moreover, the widespread life-cycle experience of domestic service almost certainly provided a conduit for both literacy and letter-writing form to the wider community, as well as creating a bank of transmissible knowledge on clothing and charity. ${ }^{36}$ In terms of their wider representativeness, I have suggested elsewhere that migration was so prevalent in eighteenth- and nineteenth-century England that it was the settled poor making their case in person, rather than the migrant poor writing letters, who were unrepresentative. ${ }^{37}$

31. On textual communities see Brian Stock, Listening for the Text: On the Uses of the Past (Baltimore, MD, 1990).

32. James Raven, Helen Small, and Naomi Tadmor, "Introduction: The Practice and Representation of Reading in England", in idem (eds), The Practice and Representation of Reading in England (Cambridge, 1996), p. 6, argue that the circulation of printed texts of this sort was stifled by rising costs.

33. See Adam Fox, "Custom, Memory and the Authority of Writing", in Paul Griffiths, Adam Fox, and Steve Hindle (eds), The Experience of Authority in Early Modern England (Basingstoke, I996), pp. 89-1 I6. For a broader approach see Hayden White, "The Value of Narrativity in the Representation of Reality", in William Mitchell (ed.), On Narrative (Chicago, IL, I98I), pp. $23-42$.

34. The issue of oral versus literate culture is expertly dealt with in Adam Fox and Daniel Woolf, "Introduction", in idem (eds), The Spoken Word: Oral Culture in Britain I500-1850 (Manchester, 2002), pp. I-51.

35. Patrick Joyce, "The People's English: Language and Class in England I 840-1920", in Peter Burke and Roy Porter (eds), Language, Class and Society: A Social History of Language (Cambridge, I991), pp. I54-190, I55-157.

36. See Jan Fergus, "Provincial Servants' Reading in the Late Eighteenth Century", in Raven, Small, and Tadmor, The Practice, pp. 202-225. Also Hitchcock, "Tricksters, Lords and Servants", pp. I83-186.

37. Steven King, "Regional Patterns in the Experiences and Treatment of the Sick Poor, I 800-40: Rights, Obligations and Duties in the Rhetoric of Paupers", Family and Community History, io (2007), pp. 6I-75. 
And while pauper letters certainly embody discursive strategies aimed at establishing entitlement and were an expression of and means of reinforcing pauper agency, they were also a mechanism for conveying very real material conditions. As Thomas Sokoll has persuasively argued, the frequency with which the out-parish poor were inspected by officials or their agents made untruths both costly and easily discovered. ${ }^{38}$ The clothing needs of writers were certainly embellished, but only within limits which were known to pauper and official. There is a sense, then, in which pauper narratives can, sensitively and carefully used, afford us a window onto the detailed everyday experiences and agency of the poor, perspective that simply cannot be obtained from any other source. Moreover, there is increasing evidence of the survival of similar narratives in other European countries, affording the potential for a broad comparative study in the future. ${ }^{39}$

Against such a backdrop, this article looks at how the experience, rhetoric and strategy of clothing was used by paupers in their engagement with Poor Law officials, drawing on 3,27I pauper letters and other associated correspondence collected from the counties of Cambridgeshire, Lancashire, Leicestershire, Lincolnshire, Northamptonshire, Surrey, Warwickshire, Wiltshire, and Westmoreland. Concentrated mainly in the period I 800-I 834 (the period of the crisis of the Old Poor Law), these letters were written from or received by the complete range of community typologies, running through London, Manchester, Birmingham, and some of the biggest industrial towns of the age right down to tiny rural communities. The narratives are supplemented by data collected from overseers' accounts, vestry minutes, settlement and removal orders, bills, and other Poor Law material for IO2 parishes within the counties mentioned above. At the core of letter samples for most of the communities in these counties are usually sets of multiple letters written by, or on behalf of, the same person or family. Such, for instance are the Curchin family who wrote 76 letters between I8I9 and 1832, or the Soundy family who wrote 38 letters over the same time period. In some places

\section{Sokoll, Essex Pauper Letters.}

39. I am undertaking further comparative work with Professor Andreas Gestrich. On the scope of this comparative context, see Louise Gray, "The Experience of Old Age in the Narratives of the Rural Poor in Early Modern Germany", in Susannah Ottaway, Lynne Botelho, and Katharine Kittridge (eds), Power and Poverty: Old Age in the Pre-Industrial Past (Westport, CT, 2002), pp. I07-I25; Robert Jütte, "Poverty and Poor Relief”, in Sheilagh Ogilvie (ed.), Germany: A New Social and Economic History, II, I630-I800 (London, I996), pp. 385-389; Marten van Ginderachter, "Public Transcripts of Royalism: Pauper Letters to the Belgian Royal Family (I880-1940)", in G. Deneckere and J. Deploige (eds), Mystifying the Monarch: Studies on Discourse, Power and History (Amsterdam, 2006), pp. 223-234; and contributions to Inga Brandes and Katrin Marx-Jaruselski (eds), Poor Relief and Charity. Rural Societies in Europe, I850-I930 (Berne, 2008). 
such series can comprise one-third or more of the total sample, though in purely numerical terms the shorter series of letters $(3-10)$ is more representative. All of the community samples include large numbers of paupers (94I in total) who wrote only the occasional letter.

For the study of textile history these narratives are particularly useful. In purely quantitative terms, it is striking that, next to sickness and housing, issues around cloth or clothing (including bedding), were the most important motifs of pauper narratives. Some $3 \mathrm{I}$ per cent $(\mathrm{I}, \mathrm{OI} 4)$ of all letters in the sample carried direct references to textiles, rising to 45 per cent (I,47I) where we also include indirect references. As far as can be judged by linking up pauper letters with overseers' accounts, vestry minutes, or inspection/money transmission records, most of the letters achieved a favourable result in terms of cash allowances granted (overseers rarely transmitted goods as opposed to money to buy goods). For the purposes of this article, however, what is important is less the success of the appeal and more the issue of how clothing was used as a rhetorical and strategic device as the poor sought agency, and what the letters tell us about the material conditions of the poor.

If the more optimistic commentators on the clothing of the poor have been right to argue that parish officers were peculiarly susceptible to the need to ameliorate poor clothing standards as the most obvious and visible sign of poverty, then we might reasonably expect paupers, paupers, we might remember, who have been assigned every greater agency and knowledge of the workings of the Poor Law in revisionist literature ${ }^{40}$ to capitalize on clothing as a means of establishing both specific (to clothing) and general (to cash allowances) entitlement. How, then, did the dependent poor talk about and use clothing in their claims-making and appeals to an Old Poor Law system in which rights to relief were few and navigation of myriad rules, local customs, and personal relationships difficult and uncertain? Pauper letters at the aggregate and individual level afford us an opportunity to address this question alongside an exploration of clothing histories, and thereby to understand much more clearly the process of English poor relief, the nature of entitlement and pauper agency, and the everyday material experiences of the poor.

\section{CLOTHING AT CENTRE STAGE?}

As a starting point, surprisingly few pauper letters place clothing at centre stage as a reason for the address or the major single instrument of claimsmaking. One contrary example is John Jump, writing from Oldham

40. See, for instance, King, "Social Inequality". 
(Lancashire) to Manchester on 2 February i 830, to note that he had lost his sight (the main reason for applying) but adding that

I am very bad in my bed Cloths which you know is very bad this weather and could wish you dear Sir to intimate this to the board and I will take it as a great favour I should have come before this but I have no Shoes to Come in I assure you with all the indeavours of my wife we are very poorly off both in bed and Clothing. ${ }^{4 \mathrm{I}}$

While Jump stopped short of tying up his request for cash relief because of loss of sight with a demand for more personal and bedclothes (leaving this to the discretion of the vestry in front of whom he wanted the overseer to present his case) his letter adopted a multi-layered language of clothing as part of conveying his state, emphasizing the serious material consequences of his lost sight, and establishing his deservingness. Thus, he implied that his lack of bedclothes in the cold weather should elicit a Christian response, that he had not the shoes to represent his case in person, and that, despite all that his wife could do (implicitly through make-do-and-mend or borrowing and buying) by way of self-help, it was impossible for such a troubled couple (and we might note the transition from "I" to "we" during the depiction of his state) to maintain their decency and ability to be in public in clothing terms. The letter conveyed material deprivation, drew on a common standard of decency, and served to reflect and reinforce Jump's agency vis-à-vis the local official.

A second example is James Sykes, a serial correspondent from St Pancras (London) to Tilehurst (Berkshire). His letter of 29 January I 829 noted that bread was dear and employment short but

$[\ldots]$ it is not in my desire to impose on the parish [...] we have got places for our two eldest daughters but they are very bad off for clothes and should be very sorry they should lose their situations on that account, but it does not lay in my power to get them any. ${ }^{42}$

While one of several issues driving the letter, Sykes clearly used the clothing of his daughters as a bargaining tool, implicitly threatening higher future bills if he could not get them into a decent set of clothes and out to work. The success of such letters requesting help with the purchase of clothing and bedding is perhaps testimony to the moral force and economic logic of the argument deployed.

These are interesting and important examples, but letters of this sort are, as suggested above, notable for their rarity. Only s per cent (73) of the individual pauper letters that made direct or indirect reference to clothing placed it at centre stage. More representative of the place of clothing in the 


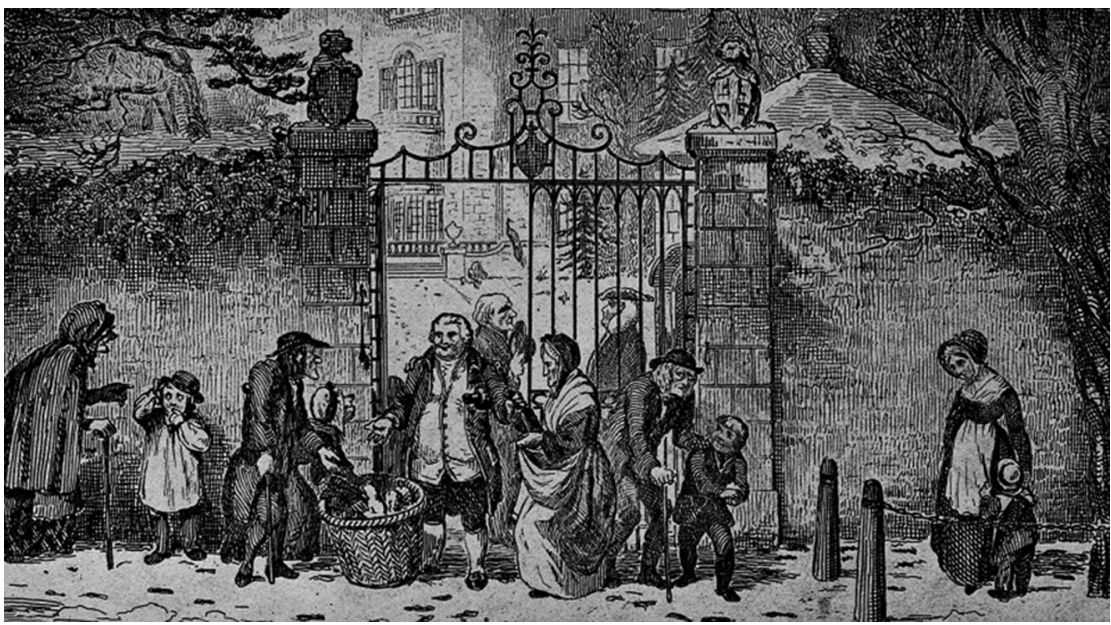

Figure I. A man stands at the open gates of his mansion handing out food to the poor who are gathered around.

Etching; Wellcome Library, London, ICV No 40573; reproduced with permission.

claims-making apparatus was George Richards who wrote from his parish of residence, Kidderminster (Staffordshire), to his parish of settlement, Thrapston (Northamptonshire), on 26 July i 824 stating that he was ill and unable to pay his rent. At the end of his letter, he added: "P.s It would be an additional act of charity to send some trifle to help to cloath the children besides the landlords demand, as they stand greatly in need of cloathes I fear you will think me too presumtuous in my demands but necessity has no law $[\ldots]$ ". ${ }^{43}$ Whether Richards was truly concerned that the overseer would think him too demanding, or whether this was a rhetorical device to emphasize his pitiful state and play on the conscience of the officials is unclear. Certainly the need to clothe children adequately (allowing them to remain healthy and get work) constituted a meeting point for the philanthropic imperative, the economic impulse of the Poor Law and the moral economy within which the agency of the poor was constructed. Figure I, an etching of an early nineteenth-century gentleman distributing food at the gates of his mansion, and in which children in poor clothing are prominent, suggests just how culturally ingrained concern over poor children and their material conditions actually was.

However, for the purposes of this article the positioning of the request almost as an afterthought - an additional act of charity rather than an 
integral part of the claim - is an important observation. By 20 September I 824, the overseer of Thrapston had not replied, and Richards wrote again, stating that he was in arrears with his rent and that "Gentlemen, part of my family at this time is destitute of clothing Such as linen or shoes which I earnestly solicit hope and trust you will take into your consideration for my motherless offspring trusting your benevolence will meet the reward of eternal blessing." ${ }^{4}$ While the issue of clothing was this time placed in the main body of the text, it was a more peripheral consideration when set against the fact that the children had lost their mother and that the whole family might end up on the streets if the rent was not paid. The fact that Richards had to write again is perhaps testimony to the overall limits of pauper agency (a theme to which we return below) but this second (and successful) appeal does begin to show how clothing could be constructed as an important yardstick of need.

It would be possible to deploy many other examples, but the key point remains that only s per cent of letter-writers placed their clothing needs at the centre of their narratives. Such figures are surprising, given the sorts of living conditions and household destitution that pauper letters often elaborate and which we might expect to feed through into compromised clothing. ${ }^{45}$ They are also surprising when set against declines in clothing and textile prices and an upsurge in availability of, and advertising for, ready-made clothing which would have raised background clothing standards and hence reinforced the symbolic impact of poor or absent clothing. ${ }^{46}$ Moreover, there is a notable difference here from settled and proximately resident paupers, who, the evidence from vestry minutes and (more tangentially) overseers' accounts suggests, frequently confronted the parish and its officials with demands for clothing. ${ }^{47}$

There are several potential reasons why the out-parish poor may have failed to use clothing as a central part of their claims-making. Most obviously, they probably preferred the flexibility of a cash payment. ${ }^{48}$ For the in-parish poor, cash spending could be more easily monitored and there may have been little to gain by requesting cash as opposed to cloth or ready-made clothing. The fact that inspection of the out-parish poor was intermittent (and hence they were less visible) might also suggest that

44. NRO, $325 \mathrm{P} / 193 / 20$.

45. On household economy see Jan de Vries, "Between Purchasing Power and the World of Goods: Understanding the Household Economy in Early Modern Europe", in Pamela Sharpe (ed.), Women's Work: The English Experience 1650-1914 (London, 1998), pp. 209-239, 229.

46. Chapman, “The 'Revolution'”, p. 5 I. Also Ross, Clothing, pp. 8-9.

47. There is not the space here to develop this line of argument, but see Sharpe, "'Cheapness and Economy", p. 203, for discussion of purchases of ready-made clothing by Colchester overseers in I8I9.

48. Lambert, “'Cast Off Wearing Apparel’”. 
building a case for support mainly or exclusively around clothing would have less effect than would be the case for the more visible in-parish poor. Moreover, there is perhaps, a sense that out-parish paupers (many of whom had been absent from the settlement parish for several years) may have had little grasp of how standards of clothing had changed in their home parishes, or that literate as opposed to oral expression created restrictive conventions on what could be requested and how. ${ }^{49}$

This is not to say that, along with the proximate poor, our letter-writers had no benchmark of the minimum standards of attire acceptable. Indeed, in the sense that many of them wrote back from large urban areas, they were likely to have been exposed to a level and range of clothing not seen in rural areas. ${ }^{\circ}$ Rather, it is to suggest that out-parish paupers might be unable to glean what it was appropriate to apply for in terms of clothing. ${ }^{5 \mathrm{I}}$ Finally (and the explanation preferred here), it is possible to argue that pauper letter-writers had a strategic appreciation of the power of rhetorical devices such as nakedness and the disabling nature of poor and absent clothing. For the poor and officials such terms were incrusted with layers of meaning, at once a reflection of the material experiences of the poor and a means of extending pauper agency, and constituted a common linguistic, material and moral currency. ${ }^{52}$

If we were to accept this viewpoint, then the fact that clothing or lack of it was not positioned at the centre of claims-making apparatus may reflect its status as the essential cement of the narrative and the claims that it embodied. It was enough to make factual or rhetorical, but ultimately tangential, references to clothing (quality, quantity, absence, loss) and the impact of its state (nakedness, inability to work, humiliation, and loss of dignity), given that paupers and officials had a shared language and spectrum of decency, a common understanding of the role of pauper clothing in shaping individual and parish identity, and a mutual acceptance of the right of the poor to negotiate relief when clothing was compromised. In this framework, the references to clothing in the letters of the out-parish poor might be regarded as the epistolary equivalent of the proximate poor turning up in rags to the vestry and having clothing granted. The two groups, in other words, shared the same clothing

49. On this matter see Roy Porter's discussion of the need for new linguistic coinage in "Expressing Yourself Ill: The Language of Sickness in Georgian England", in Burke and Porter, Language, Class and Society, 276-299, 283; and Bob Bushaway, "Things Said or Sung a Thousand Times: Customary Society and Oral Culture in Rural England 1700-1900", in Fox and Woolf, The Spoken Word, pp. 256-277, 259.

50. Catherine Richardson, "Introduction", in idem, Clothing Culture, p. I I.

5I. The out-parish poor may also have made more of their own clothing.

52. For development of this idea in a rather different context, see Porter, "Expressing Yourself Ill”, pp. $277^{-284}$. 
culture, one in which custom and morals interacted with legal obligation to put pressure on officials, and the same spectrum of material experiences. ${ }^{53}$ These are matters addressed further as we explore and contextualize the key motifs in the rhetoric of clothing and claims-making in individual pauper letters.

\section{MOTIFS IN CLAIMS-MAKING}

One of the most obvious ways in which paupers tried to deploy agency and establish their general deservingness was to stress their abhorrence of making a claim, and their willingness to do all that they could to return to independence. For most this was tied up with returning to or finding work and pauper narratives often linked clothing and work in a recitative fashion. ${ }^{54}$ Thus, when Charles Soundy wrote from Battersea (London) to his settlement parish of Pangbourne (Berkshire) on I4 May I 829 he asked for cash relief and added

I hope the Lord will enable me to git A few things to enable me to apply for A waiters place on Monday next I 8 th of May as that is the day appointed for us to meet to which place I cannot go with out being tidy in my dress and I have only what I now stand upright in."ss

Similarly, Mary Gay, writing from Bath to Bradford-on-Avon (Wiltshire) in an undated letter begged "to inform Mr Munday that she has the offer of a Situation provide she can have proper Cloths to appear decent in Mrs Culliford's service". ${ }^{6}$ Some I45 narratives in the underlying sample link clothing and work in this way. Vestry discussions of proximately resident paupers also show that work-clothing-independence was a theme in oral appeals made direct to officials, suggesting that the discursive strategy of linking entitlement with a desire to be independent and a threat to create higher future costs if not helped immediately was a common thread in the assertion of agency. The clothing requested and supplied did not necessarily have to be of high quality, as Figure 2 overleaf (showing a female streetsweeper) suggests, but the distinction between domestic and work clothing was clearly a widely understood socio-cultural norm.

53. For a development of this argument, see Bushaway, "Things Said or Sung”, p. 27 I.

54. There is no question that occupationally specific clothing was commonplace in early nineteenth-century England, and that both paupers and the wider labouring population also saw a distinction between "work" and "everyday" clothing. This is in part what pauper letters report. However, requesting clothing to allow paupers to become independent was also placing the deservingness of the pauper clearly and strategically up against the social norms of the class from which they were drawn and against which they expected officials to gauge requests.

55. BRO, D/P 9i/i $8 / 4$.

56. B. Hurley, Bradford on Avon Applications for Relief From out of Town Strays I832-I 835 (Devizes, 2004), p. 20. 


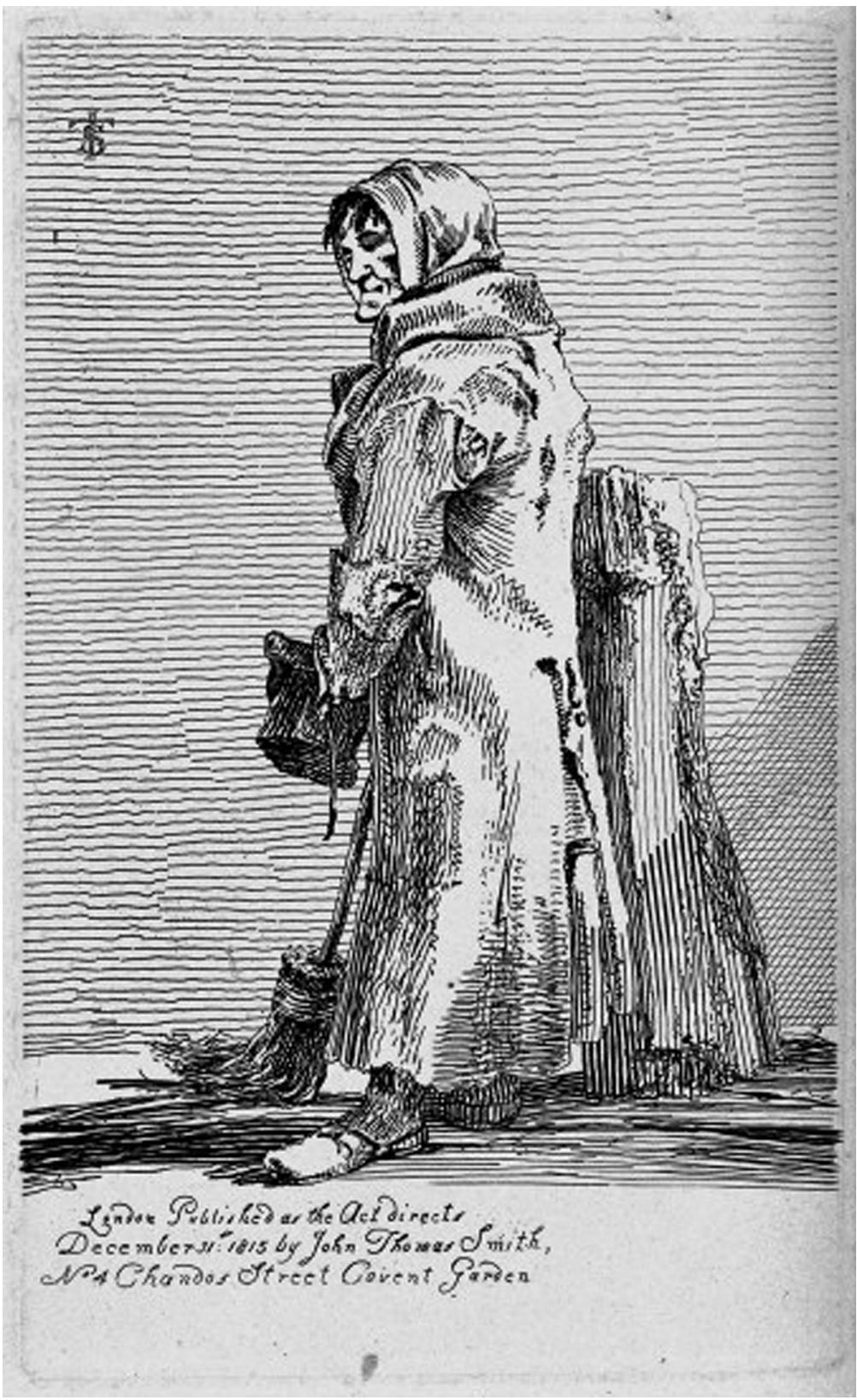

Figure 2. An old woman wearing a ragged coat leans against the stump of a tree holding a broom in her right hand and a hat in her left hand.

Etching by J.T. Smith, I8I5; Wellcome Library, London ICV No 2080I; reproduced with permission. 
We should also perhaps note in the context of the form and extent of pauper agency that the link between work-clothing-renewed independence was a much wider source of reference, strategy, and rhetoric. Thus, overseers themselves also linked clothing and work. When John Beech, overseer of Essington (Staffordshire) wrote on the subject of Joseph and John Richards to Thrapston (Northamptonshire) on i I March i 830, he suggested that "I have had a great deal of difficulty to keep them upon their legs at all for they were very bad off for clothing and have been worse off for work". A short bill for the clothing needed to allow both men to start work in the local brickyards, comprised " 3 pairs shoes 0.9.6; Worsted for stockings 0.2 .0 ; Jackets 0.5 .4 ", a significant investment in the material culture of the brothers. ${ }^{57}$

A second common motif in individual pauper narratives was to link nakedness or absence of clothing and deservingness, focusing particularly on the deficiencies of the clothing of their children and emphasizing the inability of even working parents to renew that clothing. Such an approach reported material fact, evidenced suffering, suggested a reduced standing in the community, and sought to claim moral ground in the engagement with officials. After all, there were few more powerful buttresses to pauper agency than naked and freezing children. While there are numerous examples of this in the underlying sample (236), nowhere is such a tendency better illustrated than in the multiple letters sent back from Wisbech (Cambridgeshire) to Thrapston (Northamptonshire) by Jacob and Sophia Curchin.

Sophia Curchin's letter of 25 March I 825 , one of the earliest in a series written by or for husband and wife numbering almost eighty, asked for help with rent because of Jacob's unemployment and stated, "and as for my poor children they are almost naked and I am sure that it is not in our power to clothe them. I hope you will do something for them to keep out the cold". Whether the Curchin children were genuinely naked or not (unusually, overseers' correspondence fails to clarify), this was a clear strategy to shift the family into the moral space of claims-making that the opaque law of the Old Poor Law created in respect of entitlement, particularly of children. By way of further incentive, Jacob Curchin appended a postscript in his hand, noting that "the Gentlemen of Wisbeach will have my eldest boy in the charity school, if I could clothe him but it is not in my power". ${ }^{8}$ Investing in rent would thus free resources, allowing the couple to clothe their children, while investing directly in the clothing of one particular child would bring about long-term economies for family

57. NRO, ${ }_{32} \mathrm{P} / \mathrm{i} 94 / \mathrm{i} 77$. Jutte, Poverty and Deviance, p. $8 \mathrm{I}$, reminds us that getting the poor into work "was only possible if their female and male wardrobes did not frighten away potential employers or masters".

58. $\mathrm{NRO}, 325 \mathrm{P} / 193 / 50$. 
and parish of settlement by offloading one of the children from calls on the family budget. The appeal was successful, testimony perhaps to a common understanding of the status of children as a negotiating tool between parish and pauper.

Subsequent letters brought new calls for help with rent because of unemployment or the confinement of Sophia Curchin (always a major imperative for writing) but many of them also returned to the issue of clothing for children. Letters include those of I4 November i 825 ("my Dear children are sadly distressed for cloathing. I am always mending and cannot keep them comfortable that are so compleately worne out" 59 ); 8 November I 826 ("my children are all very short of clothing to keep them warm"60); and 7 December, I829, when Sophia Curchin could

[...] take no other steps better than to apply to your goodness to assist which I hope you will do as I am sure grief will soon bring me to my grave $[\ldots]$ the Poor children are so distressed for clothing I forgot to name this before I hope you will order a coat of something for they this severe weather or I am sure they will get their deaths to come so long a journey. ${ }^{61}$

Here, then, reference to children's clothing fulfils a multiple role, emphasizing the distressed material position of the family, positing a moral case for relief, given the threat to the lives of the children, and implicitly increasing the costs of removing the family from Wisbech to Thrapston because the overseer would need to buy clothing for the children to ensure their safe passage in the winter months. Clothing in these letters was thus part of a very real drama of poor relief; the success of this and other appeals from the Curchin family illustrates the extent of pauper agency.

Adult letter-writers might also emphasize their own nakedness, as in the case of John Jump who wrote from Oldham (Lancashire) to the overseer of Uttoxeter (Staffordshire) on Is October I 83 I noting that

I have been obliged to give in Security our Bed and all other Necessaries [clothing - which is later redeemed from the pawnshop] for a little Bread for our Starving Infants and our Selves Causing our being Exposed to the Encreasing Colds of the Declining Season by Day and by Night which with other sufferings we all are in a state of the most deplorable Conditions. ${ }^{62}$

There is little doubt that paupers such as this were accurately reporting their material state. However, they were also adopting and adapting a common thread of rhetoric. Overseers and others frequently used the issue of an absolute lack of clothing to emphasize that a pauper deserved to be relieved. When William Bynns, the vestry clerk for Birmingham

59. $\mathrm{NRO}, 325 \mathrm{P} / 193 / 96$.

60. $\mathrm{NRO}, 325 \mathrm{P} / 194 / 33$.

6r. $\mathrm{NRO}, 325 \mathrm{P} / \mathrm{I} 94 / \mathrm{I} 72$.

62. King, Nutt, and Tomkins, Narratives of the Poor, pp. $24 \mathrm{I}-242$. 
wrote to the overseer of the poor of Thrapston on 29 March 1826 regarding the aged pauper, William Wortledge, he noted "the above named was received into this [work]House a fortnight ago on the commendation of Dr Ryan in a very deplorable condition not a rag to bis back and in a very wretched condition" ${ }^{63}$

Other advocates for the poor used similar rhetoric. Thus, the case of the Jump family of Oldham was taken up by local doctors and his landlady in a series of letters. On 23 October I832, Isaac Gould, surgeon of Oldham was compelled to write of the family in severe need, noting,

[...] they are a Naked and destitute family and [I] Expect their few worthless things being taken by the Owner of the house they Occupy and as to the Money Sent them Intending for the purpose of Releasing the Necessaries of Bedding from the Pawn Brokers the said place with all its Contents was Burned to the Ground the Sunday before the Money arrived. ${ }^{64}$

Notwithstanding that relief was forthcoming, Gould wrote again on I 2 August I 833 to say that "I was Struck with amaze and wonder when I entered their Miserable abode \& Garret [...] in a word the Said family is totally deprived of the Commonest Comforts by Day as by Night". ${ }^{65}$ While Gould did not directly use the term naked, he clearly and deliberately inplied their complete want of bedding and clothing, using this as a symbol of their absolute and relative need which had compromised their basic dignity. Jump's landlady, Isabella Taylor, was less subtle in referring to the clothing of the family, stating on 28 November I8 34 that the overseer should "send them a litle money for some Clothing for thar Intirley naked for Close". ${ }^{66}$ Nakedness and the absence of clothing were thus potentially powerful rhetorical instruments for paupers, but also ones that drew on a linguistic register shared with officials and other community members. The issue and implications of nakedness were, in other words, commonly understood and were vehicles for pauper agency.

The example of Wortledge above introduces a third key motif, that of the raggedness rather than the absence of clothing. As a postscript to his letter regarding Wortledge, William Bynns noted "So deplorable and filthy was the poor mans condition that we were obliged to destroy the few clothes he had on". ${ }^{67}$ Here, then, the clerk elided age and frailty with ragged clothing as an ultimate material indicator of poverty. Perhaps the situation of Wortledge was little different from the ragged crowds who attended the workhouse door to obtain food and were themselves just one

63. $\mathrm{NRO},{ }_{32} \mathrm{P} / \mathrm{i} 94 / 136$.

64. King, Nutt, and Tomkins, Narratives of the Poor, p. 248.

65. Ibid., p. 25 I.

66. Ibid., p. 257.

67. Ibid. 


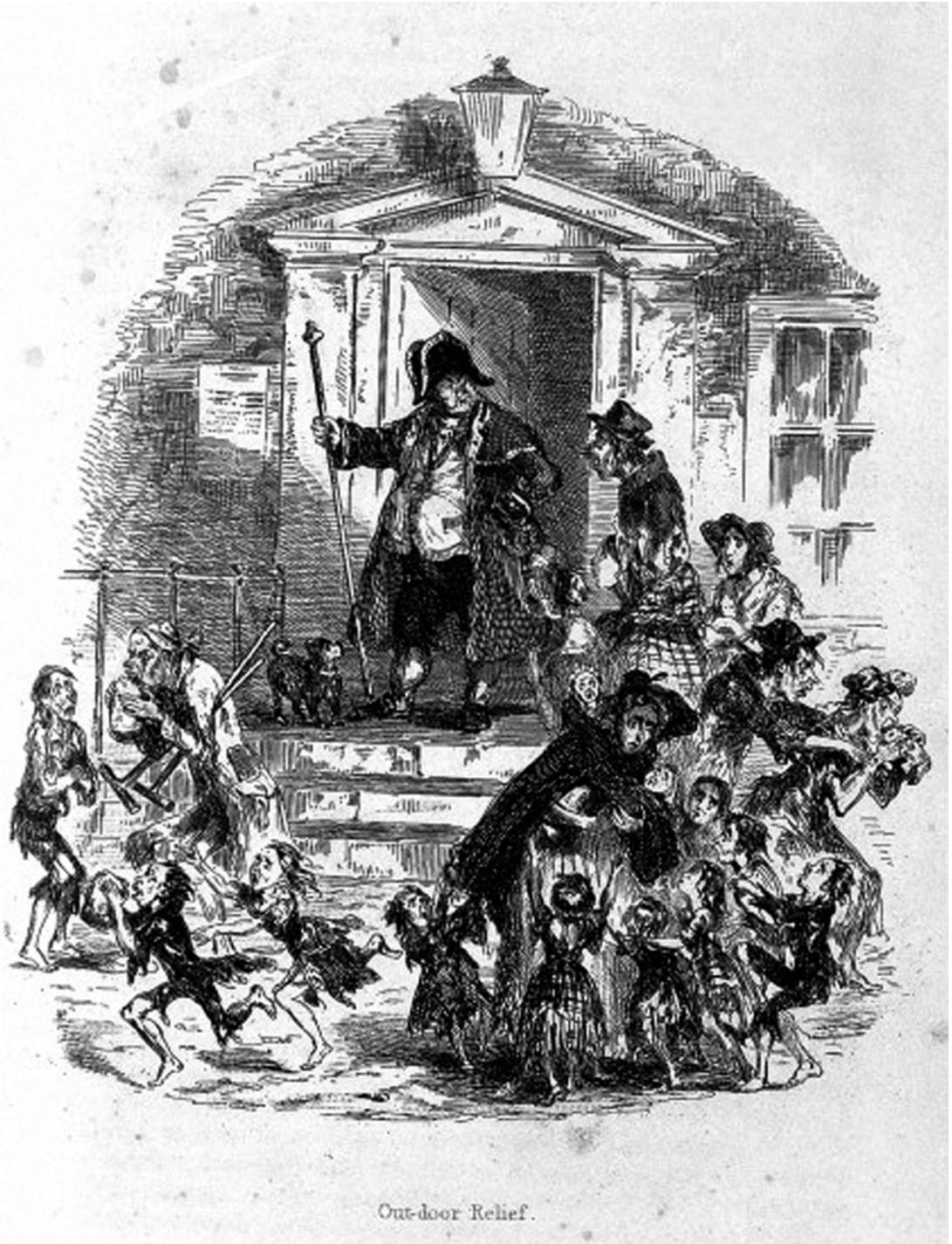

Figure 3. Caricature of poor people coming to a workhouse to get food.

Engraving, c.I840, James Grant, Sketches in London (London, I840), pp. 244ff; Wellcome Library, London; reproduced with permission.

step away from admission in James Grant's caricature of the London poor, see here in Figure 3.

Whatever the case, some IOI additional letters, by or about paupers, take up the ragged theme. For people like Thomas Earl the impression of raggedness was given by placing a monetary value on the clothes, no 
doubt in the certainty that such values were a commonly understood yardstick when it came to assessing clothing. His letter from Southampton to Bradford-on-Avon of 2 I November I 833, for instance, claimed that "neither of it [his clothing] is worth six pence". This was a very small sum indeed, given our renewed appreciation of the vibrancy of the secondhand market, and was meant to convey the extraordinary paucity and material condition of his clothing. ${ }^{68}$

Other paupers referred not directly to the raggedness of their clothing, but emphasized the age of what they had. In response to a note from the overseer of Bradford-on-Avon doubting whether she was still eligible for relief, Ann Jones wrote from Freshford (Gloucestershire) on I 8 September I834 to say that "the best gown I have is a cotton one I bought of Mr Watts seventeen years ago" ${ }^{69}$ Most commonly, however, paupers linked ragged clothing and their visibility in the community, drawing an explicit link between clothing and identity, something that would have been well understood by officials. Thus, Jane Powell wrote from Warwick to Rothershorpe (Northamptonshire) on 24 June 1833 to say "And as for my Clothes they are beyond the Mending and me and my Children not Fitt to be seen in the neyburhood". ${ }^{\circ}$

While the absence or loss of clothing kept paupers indoors, ragged clothing, as Buck reminds us, was the most visible badge of poverty, something that increased the shame of the pauper at the same time as it advertised the failure of communal welfare. Raggedness, then, was a powerful tool, describing the material condition of clothing but also symbolic of compromised dignity and a cause for paupers to assert their moral rights to be part of the community. ${ }^{71}$ Figure 4 overleaf, a depiction of an insane pauper clothed in ragged and patched clothing and reputed to have lived in a field, provides some indicator of the way in which raggedness, lost dignity, and the failure of community could be tied together.

A final key motif in pauper narratives was the sudden loss of clothing, usually to the pawnbroker, at once evidence of suffering and the attempts of the family to make do, and a rhetorical strategy that could merge seamlessly into nakedness, shame, and the Christian duty of the overseer or vestry to offer relief. Loss of clothing was, in other words, the last straw. Thus, we might witness Jacob Curchin, encountered earlier, writing to the overseer of Thrapston on 2 February I 826 to say that "I have been obliged to pawn what few cloathes we ad to get some medicine for my wife as it was quite out of my power to get food." ${ }^{2}$ The elision of lost clothing with starvation and sickness places the issue of entitlement and

71. Buck, Dress in Eighteenth Century England, p. I05.

72. $\mathrm{NRO}, 325 \mathrm{P} / \mathrm{I} 93 / \mathrm{I} 19$. 


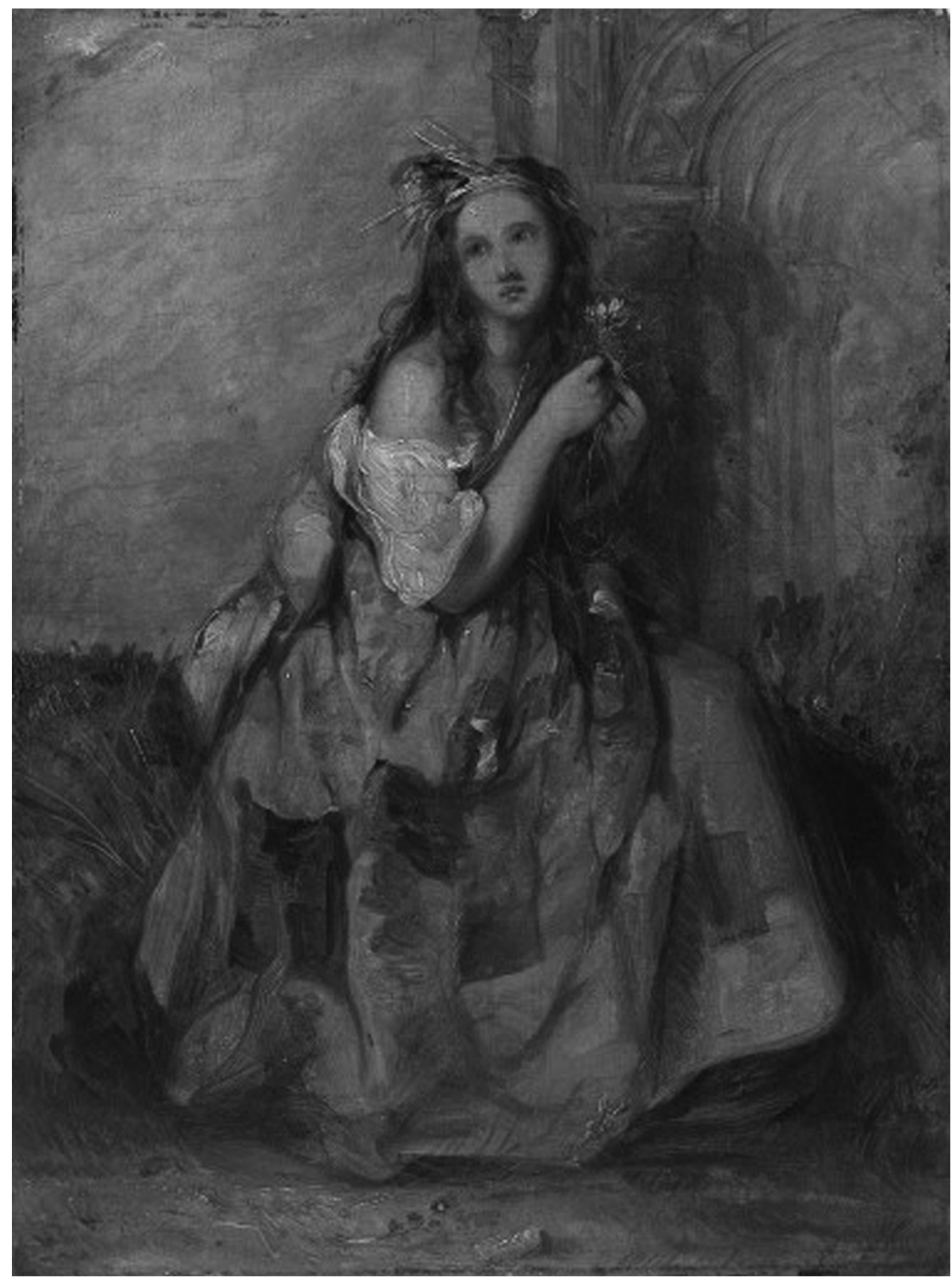

Figure 4. Portrait of Mad Margery, a young woman driven mad and living in the fields; she is wearing patched clothes, holding flowers, with straw in her hair and dirt on her face, her eyes watery with tears. Oil painting by James Hill, c.1835; Wellcome Library, London, Iconographic Collection $603136 i$; reproduced with permission.

the potential response of the official firmly within a moral framework, and is a good indicator of the agency of this particular pauper. Unsurprisingly, relief was given. 
There are numerous other examples of this sort of discursive strategy, almost all of them successful. Philip James wrote from Leicester to Uttoxeter (Staffordshire) on I 2 June I 834 to say that "I have Pawnd E Sold till Myself $\mathcal{E}$ Family are quite Destitute of the Necessarys of Life". ${ }^{73}$ The example of William Bromley provides more explicit testimony as well as highlighting the potential for multiple rhetorics of clothing in pauper narratives. He first wrote from Shrewsbury (Shropshire) to Condover (Shropshire) on 20 April I 817, suggesting that during six weeks of unemployment,

[...] we have been forced to pledge Every Nessary articl we have but what we now stand in Even the sheets of our bed to support us be side going debt and not been able to pay tho have put me in the Court and besides we have been three parts fameshed for want of Vituals being Seven in family and my Children have took the peelings out of the pigs wash and Eate them for Hunger nor have i gote one bite of Vituals to give them nor half a penny to buy and my wife is Verry bad and Near her lying in and if the Child was born to day she as not an Article to put on it. ${ }^{74}$

This is a very subtle letter hinting at the loss of a full range of clothing and bedding, tying up lack of clothing with the humiliation of having to forage like animals and the threat to a newborn infant occasioned by not even having the clothes to dress it at birth. These would have been powerful yardsticks of need for the Condover officials at the same time as they were a sophisticated rendering of, and vehicle for, pauper agency. Describing the loss of clothing and its impact was, as Catherine Richardson points out, a way of giving meaning where a linguistic register was insufficient to convey the depth of despair. ${ }^{75}$

Bromley wrote again on 9 July I 8 I 7 . Alongside his other key yardstick of deservingness, hunger, we find a forceful rendering of the state of his and the family's clothing,

[...] beside $\mathrm{i}$ have not a shirt upon my back nor have $i$ ad any Sence friday last for i have pull it of Every week for thees four Months for my wife to wash till it is not fite to wash nor wear any longer so that $i$ am ashamed of going out of the doors the way $i$ am tho $i$ have Cloaths in pledge that would make me four but you will not give me above 2 or 3 shillings at a time so we are not able to Baik a loaf of bread nor Redeem an article out of pledge with it [...]. Nor nither due I wish to put you out of the way in Rifling your temper for $i$ no you have a verry hard task to pleas Every ones temper but indeed we Cannot be Exposed in the way we are in for want of our needfull Nessarys beside three parts Clemed. ${ }^{76}$

73. King, Nutt, and Tomkins, Narratives of the Poor, p. 277. Buck, Dress in Eighteenth Century England, p. I4I, argues that having to pawn "best" clothes had a fundamental impact on the labouring psyche and that the distinction between best and everyday dress was only "abandoned in extreme poverty".

74. King, Nutt, and Tomkins, Narratives of the Poor, pp. 284-285.

75. Richardson, “'Havying Nothing upon Hym", p. 220.

76. King, Nutt, and Tomkins, Narratives of the Poor, pp. 286-287. 
There are several potential readings of this letter, but the one preferred here is that Bromley was deliberately using a multi-layered rhetoric of clothing loss, shame, exposure, and poor clothing quality to enhance his deservingness. What clothes he had were falling apart through sustained washing and wear occasioned by the fact that his alternative clothing remained constantly at the pawnbroker. This is an excellent rendering of the material experiences of poverty. In his current state of affairs, however, Bromley was unable to venture out. His clothes had created a new and shameful identity for an otherwise respectable man. ${ }^{77}$ Bromley was plainly aware of his irritation value to the overseer, but he used the multi-faceted phrase "we cannot be exposed", with its economic, cultural, clothing, and power-relationship connotations, to justify his further letter.

While Bromley is a particularly good example of the way in which clothing loss could be used by paupers as a key tool in extending their scope for agency, in the wider sample this sort of approach to establishing deservingness is common. Interestingly, epidemics and episodes of severe sickness that resulted in clothing having to be destroyed also figure prominently in these narratives of clothing loss and (see Figure 5) more widely in the spectrum of visual sources.

\section{CLOTHING AND MULTIPLE LETTER-WRITERS}

Bromley's letters begin to suggest not just that individual pauper narratives contained distinctive rhetorical and strategic motifs linked to clothing, but that paupers (or those writing for them) could develop the material picture and wider rhetoric of clothing over several letters, gradually introducing the motifs explored above and joining them together to create a picture of compromised dignity and respectability, parish obligation, generalized deservingness, and an altered ability to function in their host community. We can exemplify some of these themes through a series of letters written by or on behalf of the Soundy family from Battersea (Surrey) to Pangbourne (Berkshire), between the late i 8 Ios and the early i 830 .

We first hear of the family in December i 8 I 8 (Letter I), when Frances Soundy (the wife) wrote to ask the overseers for relief because she had been abandoned by her husband after a family argument. The first reference to clothing in this series of letters was when $\mathrm{Mr}$ Ambrose, perhaps a neighbour, wrote on behalf of the family on I 6 September I 823 (Letter 4) to say that they wanted to apprentice one of their sons but "as he [James Soundy, the father] will have to procure him with Cloaths $\mathcal{E}$

77. See Richardson, “'Hauying Nothing upon Hym”, p. 2 I 8. 


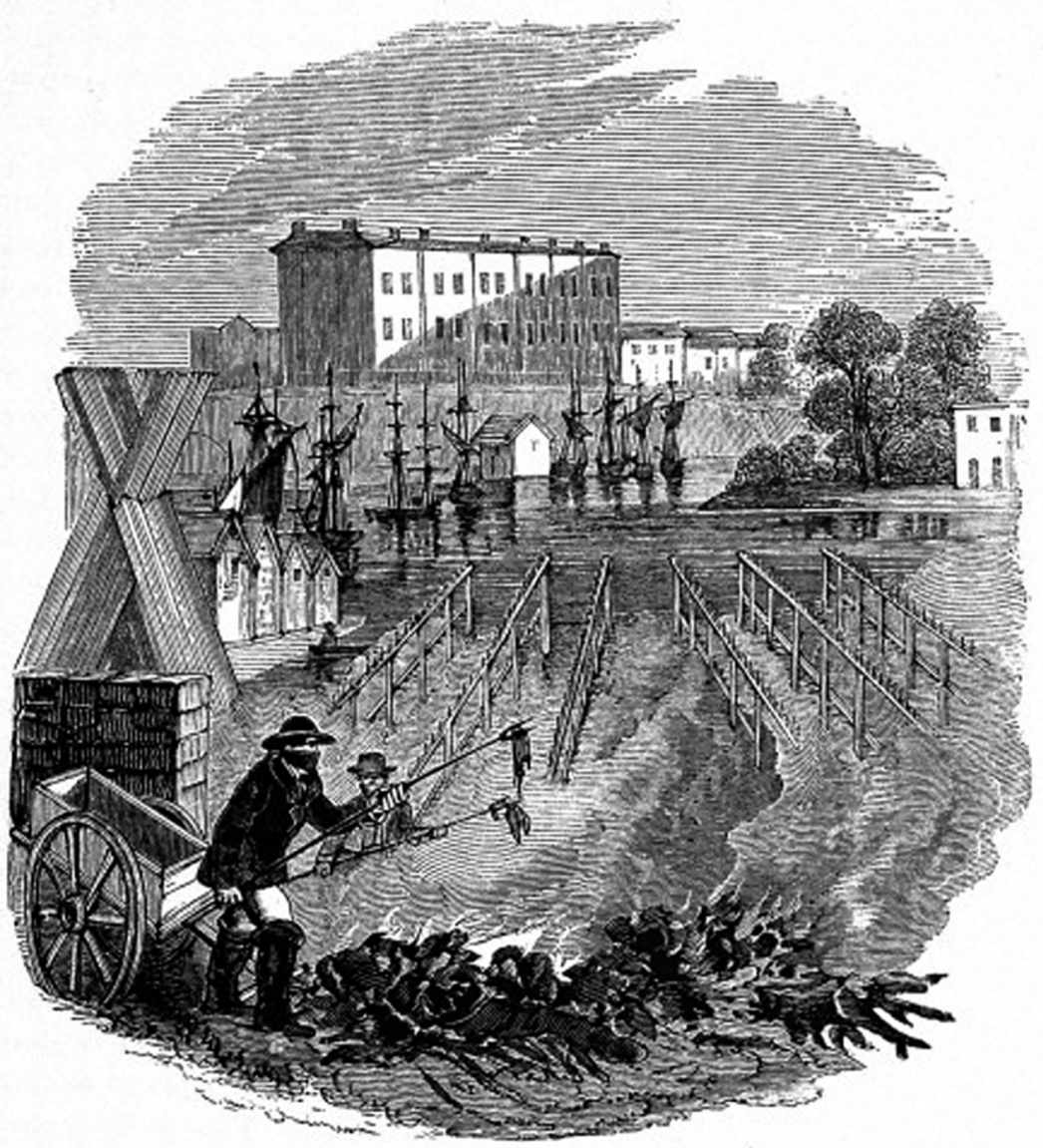

Figure 5. Burning clothing infected with cholera in Exeter, I 832.

Thomas Shapter, The History of the Cholera in Exeter in 1832 (London, I849), p. I83; Wellcome Library, London; reproduced with permission.

washing during the time he humbly hopes you will in your goodness defray the expences of finding which is about four Pounds".$^{8}$ As Jones, Honeyman, and others have pointed out, the requirement to find clothes for apprentices from poor families figures often in overseers' accounts and 
was also a common motif for the in-parish poor. ${ }^{79}$ Frances Soundy took up the same theme with two letters later in 1823 (Letters 5 and 6), informing the overseer in one of them that the child still needed clothes and that the money they had saved for this had already been spent supporting his elder brother. ${ }^{80}$

This interlinkage of work and clothing, a distinct motif in its own right as we have already seen, was developed in a letter from Frances Soundy on I 8 February i 824 (Letter 8) which noted that they had pawned their bedclothes but

I ham happy to inform the gentleman that my husbands thumb is now mending and the doctor says that he hopes he will be able to work in a fortnight so that we humble entreet the gentellmen to remit to battesea oversears our rant and a pair of shoes for my busband as he can not go to work without danger of having nales run in to bis feet. ${ }^{81}$

Soundy thus combined two of the key motifs in the wider sample of narratives, implying that clothing has been lost to the pawnbroker or sold in the market, and emphasizing that a certain minimum level of clothing (a pair of shoes) would be needed to get her husband back to work after his illness. The work-clothing interlinkage continues in a letter of $\mathrm{I}_{3}$ February I 826 (Letter 9), the start of a sequence of letters in which the issue of clothing moves increasingly centre stage. Noting that she provided houseroom to her son, daughter-in-law, and grandchild, and that they were in considerable debt, Frances first employed the idea that clothing was enabling, for,

[...] my Son now would i exspet git in to work in a week or 2 if he ad deasant things to put on but he can not put feet out dores for he have not a shoe to bis feet and he must apeer tidy be fore the gentillmen and it do not lay in my power to git him any. ${ }^{82}$

By spending a little on clothing now, the overseers would, in other words, relieve the suffering of the family and reduce parochial liability for future bills.

Clothing was a vital prop to work and independence. Even at this stage we see a complex rhetorical style that intertwines the deservingness of the old couple with the fate of their children, one that is developed further in a letter of I 6 November I 826 (Letter I I). Its central strategic focus was on

79. Jones, "The Clothing of the Poor", p. I3; Katrina Honeyman, Child Workers in England 1780-I 820: Parish Apprentices and the Making of the Early Industrial Labour Force (Aldershot, 2007).

80. $\mathrm{BRO}, \mathrm{D} / \mathrm{P}$ 9I/I $8 / 4$.

8. Ibid.

82. Ibid. As Buck, Dress in Eighteenth Century England, p. I05, reminds us, the visibility of the wearer shaped acceptable clothing standards. 
the emotional and financial costs of keeping the son and his wife and child, but the claims-making rhetoric was firmly fixed on the issue of clothing, housing and food. Thus,

I have dun a grat deal un none to my husband and distressed my salf and other children till we have nothing now left that $i$ can assist them any longer $i$ shuld have bene happy to have dune it for it is a grat trobele to my mind to see my chilldren starving and can not help them for $i$ have now brot my self to grat disstres gentillman $[\ldots]$ i humbly pray that you will whea [weight] their misfortunes in your hone brast [breast] and think wot a Mother must feel in seing her children starving and naked $[\ldots]^{83}$

From clothing being enabling it had come to be disabling, on a par in terms of yardsticks of deservingness with other absolute indicators such as starvation and homelessness, with a suitably stark language of nakedness, itself a motif in individual pauper letters. Faced with this picture of material deprivation, the parish remitted $£_{2}$.

However, by I February I 827 the money had been spent and Frances wrote once again (Letter I 2) to Pangbourne, emphasizing that she now had two adult sons co-resident. This situation had brought them to the greatest distress. Unable to use the analogy of nakedness so soon after receiving $\mathfrak{£}_{2}$, Frances turned to the impact of her troubles on the quality of her own clothing suggesting that "gentill men I have distressed my salf so that $i$ can not go out of dores for want of things to keep me warm". She also reiterated the link between clothing and work insisting,

[...] if the honerable gentillmen will be so kind to assist him [the son] with a small trifell to git him a pair of shoes and a pair of trowerss so that he may be able to go to work wich i expect now will be in a short time if the wather keeps fine. ${ }^{84}$

With no answer forthcoming (itself a reflection of the limits of her agency), Frances wrote again on 23 February I 827 (Letter I3), suggesting that the opportunity for work for the son had been lost because he did not have decent clothing and asserting that she has reached the end of the road in terms of her very dignity and public persona for " $i$ can asure you that $i$ have this day bene oblige to take my gound [gown] from my back and pairt with it to surply us with breed wich his vary hard and to live haf starved as i do". 85

Here, then, we have the familiar motif of the sudden loss of clothing that in emotional, strategic, rhetorical and material terms is the last straw. We have, in other words, been moved on a spectrum of experience from need linked to supporting adult children, which could be alleviated through some enabling spending on clothing, through the rhetoric of

83. BRO, D/P 9i/I 8/4.

84. Ibid.

85. Ibid. 
nakedness or inadequate or ragged clothing, to the loss of clothing as the final straw in the descent into absolute destitution. For Frances Soundy, taking the gown from her back was the last symbolic resource she had to keep her independence and perform her motherly and wifely role. ${ }^{86}$ It is hard to imagine, for a female pauper, a letter which so firmly sets entitlement on a moral compass, or one that so keenly displays the range of discursive strategies that might underpin pauper agency.

After receiving this letter, Pangbourne remitted relief and Frances Soundy once again began to build her case for more, melding together unemployment, hunger, compromised dignity, and compromised clothing into a generalized narrative of deservingness, specifically referring to clothing in October I 829 (Letter I 8), November I 829 (Letters 20 and 2I) and building to a crescendo in a letter of February I83 I (Letter 28), in which she suggested that her daughter could be put out to work if Frances could "get her close Redey", that she could sell things in the street but for the fact that she had pawned her clothes and that "we do not live gentlellmen we only servive". ${ }^{87}$ Lost clothing was thus disabling for the whole family, hedging them into the domestic sphere and cutting them off from the world of work and independence so that they only survived rather than lived. Whether Frances Soundy was giving a true picture of the material culture of her family is unclear, though Pangbourne paupers were inspected regularly so there was little opportunity to embellish very strongly. In some ways this matters less than the fact that she wrote about it because she clearly expected the overseers to be susceptible to claimsmaking centred around clothing. Pauper and overseer had, in other words, a shared understanding of the moral, rhetorical, and linguistic territory on which deservingness might be established.

The Soundys are a particularly well-documented couple, but they are by no means unusual. The underlying sample contains $23 \mathrm{I}$ individuals who wrote multiple letters and for whom clothing was a regular rhetorical feature of the narrative. Such paupers clearly thought clothing to be an important element of their claims-making alongside homelessness, death, child suffering, and starvation, and where we have a series of letters at our disposal it is clear that issues of clothing become more important as the series develops and that such paupers interlinked multiple clothing motifs in order to establish deservingness. If clothing was not centre stage in most individual pauper letters, it could easily become so during the course of a series of such narratives, suggesting pauper awareness of the discursive importance of clothing.

86. There is clear support here for Richardson, "Introduction", p. 22, who argues that clothing held emotion within their materiality. Soundy was not just losing a gown, but her identity.

87. $\mathrm{BRO}, \mathrm{D} / \mathrm{P}$ 9I/I $8 / 4$. 


\section{CONCLUSION}

The exact constellation and quality of clothing provided (or purchased using money provided for the purpose) by the Poor Law remains unclear, though it is apparent from vestry minutes, overseers' accounts, and pauper letters that there probably was a common understanding of the contemporary term "necessitous clothing". Falling textile prices (especially after I8I5) and the rise of the ready-made and second-hand trades almost certainly increased the benchmark of acceptable clothing levels over time, making the compromised clothing standards of paupers reported in pauper letters even more stark. More work is clearly needed on this issue.

However, what is clear is that paupers used and understood multilayered rhetorics of clothing - raggedness, clothing loss, clothing and public persona, clothing and work - in their attempts to gain specific forms of relief from their parishes of settlement and in building (usually via multiple letters) a generalized case for relief. There are, of course, many nuances but three core conclusions suggest themselves. The first is that pauper letter writers (and we might easily extend this to the in-parish poor who attended the vestry) saw Poor Law officials as susceptible to an argument that tied up deservingness with the state of their clothing. It is easy to over-read such sources, but one interpretation is that pauper language was carefully chosen so as to reflect/report, construct, and constitute the experience of poor clothing, at once melding together their own understanding of decency, dignity, and eligibility with wider community norms on acceptable clothing. For our pauper correspondents, compromised or absent clothing was both cause for specific relief and "an authenticating process" for more general entitlement. ${ }^{88}$

A second conclusion is that Poor Law officials were susceptible to the rhetoric of clothing, which like death and starving children, represented a negotiating space in which economy, moral and customary obligation, legal rights and duties, and the deportment of the poor intermixed in the decision over eligibility. Overseers acceded to most requests for clothing from the out-parish poor, much as they did for their in-parish counterparts. ${ }^{89}$ Fulfilling pauper requests for clothing had a consequence for the Poor Law, on the one hand establishing precedent and custom but on the other advertising beneficence, paternalism, and belonging. The fact that some overseers in their correspondence with other parishes saw prevarication on clothing as shameful suggests that officials had limited room for manoeuvre.

In turn, and related to this observation, a third conclusion is that there is evidence that paupers and officials used the same linguistic register and

88. Richardson, “'Havying Nothing upon Hym”", p. 2 I4.

89. Ibid., p. 220. 
slate of accepted understanding when they wrote about clothing. While we must be cautious in constructing pauper agency, in terms of an understanding of the symbolic, practical, and linguistic importance of clothing, paupers clearly held important cards in their hands to underpin negotiations with officials, who on these matters at least were probably obliged to listen. The fact that appeals often had to be repeated suggests that pauper agency was not as robust or extensive as some have suggested, an observation that sits well with Peter King's recent analysis. ${ }^{\circ}$ However, rhetorical strategies centred on clothing, in particular those that exploited commonly understood standards of decency, do ultimately seem to have translated to eligibility for relief. As clothing became cheaper and clothing charities expanded in scale and scope, it perhaps became ever less acceptable for officials to scrimp on the clothing of their dependent parishioners. 